\title{
A SWAINSON'S HAWK STAGING AREA ALONG THE MISSOURI COTEAU IN SOUTHEAST SASKATCHEWAN
}

\author{
MARTIN BAILEY and CAROL BJORKLUND, 102 - 1833 Coteau Avenue, Weyburn, \\ SK. E-mail: cmbb@sasktel.net
}

Carol Bjorklund was informed the morning of September 23, 2004 by fellow school bus driver, Russell Moe, that he had seen hawks in the fields for almost a week as he made his rounds. On the evening of September 23, between 5:30 p.m. and 7:00 p.m. we began observations of these hawks-Swainson's Hawks-using a twenty power Bushnell Sentry II spotting scope, eight power Burris and Zeiss binoculars and the truck as a blind.

We made observations on the numbers of Swainson's Hawks from September 23 to October 4, 2004. Over 2,200 were noted between September 23 and 30, and none was reported after this date. The area where the hawks occurred encompasses eight sections (eight square miles) of farmland five miles north of Weyburn. The sections (13 to 16, 21 to 24) lie within township 9-15W2, at approximately $49^{\circ} 44^{\prime} 55^{\prime \prime} \mathrm{N} 103^{\circ} 55^{\prime \prime} \mathrm{W}$.

This total area is under cultivation. Abandoned farmsteads and a few remaining farmyards provide the only trees available for roosting. Hay bales filled three half section ( 3 x 320 acres) fields but we did not observe hawks perched on these, either day or night .

The crop land farmed in 2004 was seeded to wheat, oats, canola and flax. At the time of the study, much of the crop land had already been swathed or combined, leaving stubble with just the stalks of the crop remaining on the fields. Farm land that had lain fallow during this growing season had either been plowed under (summer fallow) or fallowed using herbicides (chemical fallow).

\section{September 23, 2004}

Over 500 Swainson's Hawks were counted in a quarter section chemical fallow field ( 160 acres) on September 23 between 5:30 p.m. and 6:30 p.m. The hawks were feeding on grasshoppers. Between 6:30 p.m. and 7:00 p.m. they flew across a road allowance and either landed in a stubble field on the other side of the road allowance or went directly to an abandoned farmyard a quarter of a mile away where they roosted in a grove of trees. By 7:00 p.m. (approximately fifteen minutes after sunset) all the birds had flown to the trees to roost.

\section{September 24, 2004}

When we returned to the farmyard the next morning at 9:45 a.m., the hawks were already rising up in kettles (spiralling upward on updraughts of air) and quickly disappearing southward. They were coming out of the roost trees and off the ground near the trees. Within this area - a section of land (640 acres)more than 1,100 Swainson's Hawks were rising. In another field farther south, another 100 Swainson's Hawks were rising in kettles and moving south.

At 6:00 a.m. the Weather Network reported a temperature of $2^{\circ} \mathrm{C}$. At 9:30 a.m. it was $10^{\circ} \mathrm{C}$. By 10:45 a.m. an air temperature of $20^{\circ} \mathrm{C}$ was recorded at the farmyard. The morning was dead calm with barely perceptible breezes from the east. The wind shifted to the southwest and then quickly turned to west by southwest at Beaufort four (12.4-18 mph).

In the evening, we travelled north on Highway 35 to a gravel road heading west, 22 miles north of the earlier sightings. Going west and back south again, we went back and forth towards the evening roost of the night before. 
No Swainson's Hawks were found north of the roost site.

\section{September 25, 2004}

In the morning, 519 Swainson's Hawks were counted at the first site and the adjacent two sections of land. The hawks began to rise skyward at 10 a.m. in a south by southwest wind at Beaufort three (7.4-12 $\mathrm{mph}$ ) increasing to a Beaufort four, and continued on to $11: 30 \mathrm{a} . \mathrm{m}$. with the winds gusting to a Beaufort five (18.6-23.5 mph) out of the southwest.

While there was more than one location where the hawks were spiralling upward, one of the most used locations was a mile and a half south, and one mile west, of the original site. Upon examination, we found that it was here that four quarter sections met: a field sown to oats, another to flax, a chemical fallow field and a summer fallow field. At this intersection, the land was slightly bowed with a gradient that was no more than 10 inches lower than the surrounding soil. The earth was black and the ground temperature at the centre of this dimple was $27^{\circ} \mathrm{C}$. The air temperature was $21^{\circ} \mathrm{C}$.

In the evening, 84 Swainson's Hawks were located in a distinctively orange-coloured field, the telltale sign of the chemical fallow field. By 7:00 p.m. they had all gone to trees on a quarter section of land a mile west.

\section{September 26, 2004}

By 9:10 a.m., 64 Swainson's Hawks in two groups were kettling, leaving eight of their mates in the stubble near the night-time roost. The soaring birds headed south, as did the authors.

At 10:10 a.m. we noted a large flock of Swainson's soaring and gliding over Weyburn, heading in a southeasterly direction. Given that we had seen almost 2,000 Swainson's Hawks going over Nickle Dam, (see Figure 1) southeast of Weyburn three years earlier, we headed to the dam. No hawks were observed at the dam, however.
Continuing on south and east through pastureland to high land overlooking Roughbark Creek (which runs south and then east into the Souris River), we caught glimpses of Swainson's Hawks heading south by southeast. Soon we ran out of road and drove along a trail and forded a creek before coming out to paved road that took us across the Souris River. From there to Estevan no more Swainson's Hawks were observed.

\section{September 27 - 30}

Daily observations were resumed on 27 September, at the site north of Weyburn. Swainson's Hawks continued to arrive in the area after 27 September but the numbers counted steadily declined from 175 on 27 September to seven on 30 September. Although observations continued until 4 October, no more hawks were seen in the area after 30 September.

The number of Swainson's Hawks seen leaving the area from 23 September until 30 September was 2,289.

\section{Summary}

No Swainson's Hawks were seen in fields where the crop was still standing, even though some were thick with grasshoppers. These fields were too dense with vegetation for the hawks to move about in and too high for them to see within. Summer fallow fields, which were clear of all standing vegetation, were totally without attraction to grasshoppers.

The hawks were sometimes found, before they flew up to roost for the night, in stubble fields adjacent to the roost trees. In the morning, as the sun began its rise over the horizon, hawks would be noted in the stubble where they stayed until they either flew to chemical fallow fields or began to kettle.

The hawks foraged in chemical fallow fields where some vegetation could be found. Foraging began after the ground temperature reached $17^{\circ} \mathrm{C}$. Perhaps at this temperature the grasshoppers began moving about and were then noticed by the hawks. 


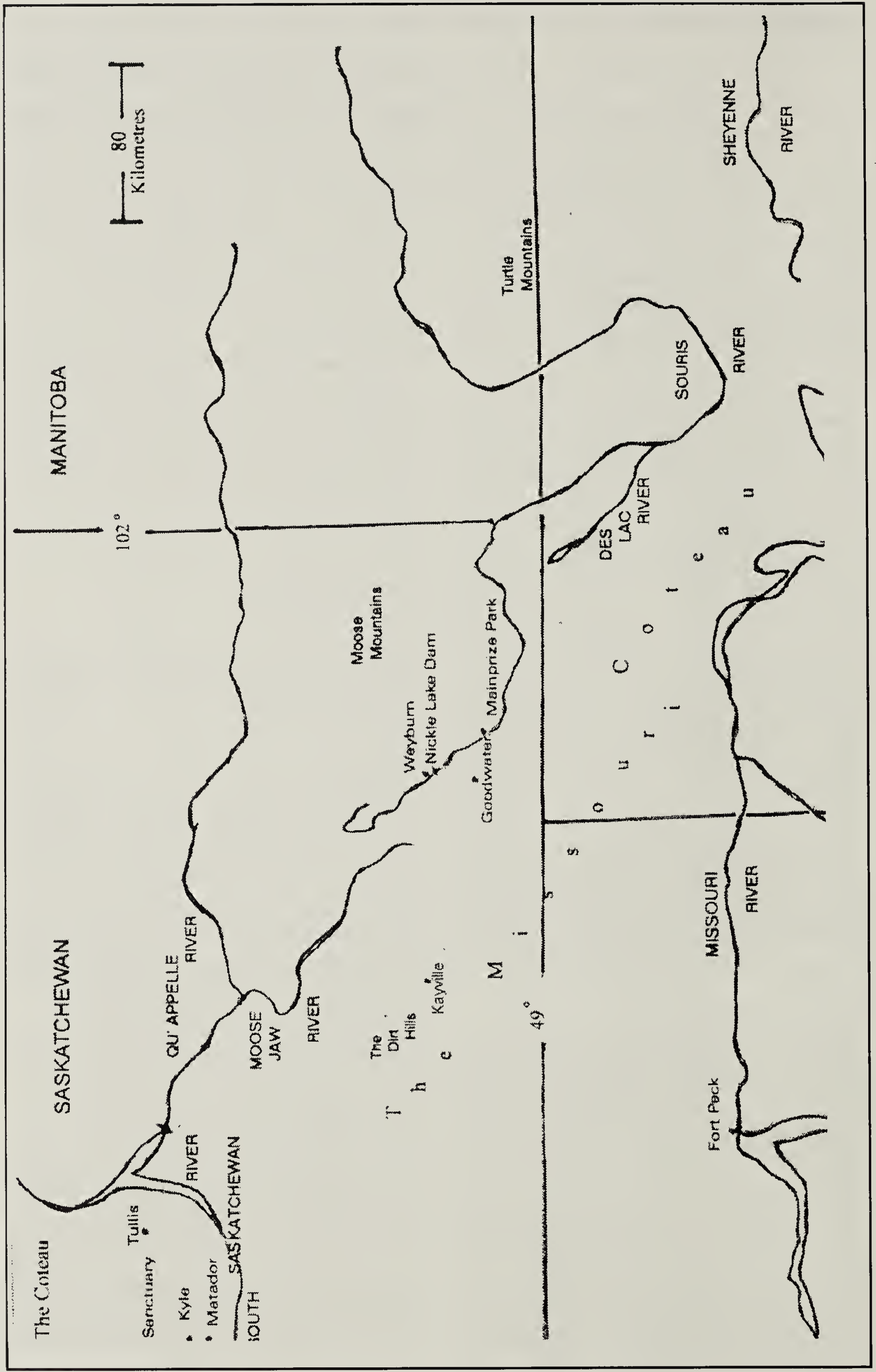

Figure 1. Locations along the Missouri Coteau mentioned in the text. 
Roosting began before 6:30 p.m. at night and continued to 7:00 p.m., approximately fifteen minutes after sunset. The hawks came out of the trees just before sunrise. On September 27, within a half hour of sunrise Swainson's Hawks were located a mile away from their overnight roost.

Winds normally started from a dead calm at sunrise and increased to Beaufort three or four by noon over the observation period. Typically, winds were from the east just after sunrise and could shift around until they came out of the northwest as the day progressed. No winds were noted from due south or due north.

Normally, winds from Beaufort three or four, with air temperatures above $21^{\circ} \mathrm{C}$ after 10:00 a.m. created the conditions for the hawks to kettle and disappear to the south and southeast. However, on 26 September with an air temperature below $20^{\circ} \mathrm{C}$, but with winds gusting to Beaufort five out of the northwest, 64 Swainson's Hawks swirled up and vanished into the southeast by 9:15 a.m. On the other hand, on 27 September with the dark earth below a kettle at $30^{\circ} \mathrm{C}$ and but a wisp of wind, 24 hawks rose on air currents.

Numbers observed varied from over 1,200 on the evening of 24 September to seven on 30 September, the final day that hawks were seen. It simply was not possible for two ground level observers to see everything that could take place in this area at any one time. Nevertheless, it is assumed that flights did not begin before 9:00 a.m. and that the last birds to arrive in the study area came by $5: 30$ p.m. It is estimated that the median flight day for the Swainson's Hawks that came in and went out of the study area started around 10:00 a.m. and lasted until 4:00 p.m.

\section{Other observations along the Missouri Coteau}

The Elbow

Swainson's Hawk records in this area go back 60 years to " the night of 31 August, 1943 , a flock of 80 roosted in a few large poplars at the Roy farm, near Tullis. They returned, but in diminishing numbers, each succeeding night until 12 September. On 23 September, 1986, Robert Wapple counted at least 86 in a stubble field $10 \mathrm{mi}$. north of Kyle. On 20 September, 1972 near the Matador 138 took shelter in a $0.62 \mathrm{mi}$. shelterbelt during a snowstorm (Sig Jordheim)..... Bernie Gollop counted 300+ hawks, mostly Swainson's but with a few Red-tails, in a stubble field northwest of Sanctuary, $16.7 \mathrm{mi}$. south of Elrose, 14 September, 1981. As he watched, most took off in a southeasterly direction. On a clear morning after a rainy spell, 16 September, 1959, Evelyn Boon, Tullis, witnessed a remarkable flight of 700 hawks, the majority apparently Swainson's, flying over the farm from the northwest. She counted them as they passed between the power poles (Boon, 1961, Blue Jay)." ?

All these locations are at the northern lip of the Missouri Coteau where "Towards the end of August, Swainson's Hawks begin to gather in large, loose flocks, generally numbering between 20 and 40 birds. They spend the days in field and pasture feasting on crickets and grasshoppers before retiring to telephone and power poles or farm groves to spend the night. Sometimes every telephone pole for a kilometre or more will have a hawk or two roosting on it." 7 More recently on September 25, 1996 another $300+$ were on high ground ten miles north of Kyle. (G. Pederson, pers. comm.)

\section{Dirt Hills}

Heading southeast from "The Elbow" and skirting the Dirt Hills-land fronting the Missouri Coteau—200 plus Swainson's Hawks were seen in fields near Kayville on September 21, 2002. The observers assumed that the hawks were grounded by unsettled weather; cloudy skies, $5^{\circ} \mathrm{C}$ temperatures and driving rain. ${ }^{10}$

Satellite tracking of 34 Swainson's Hawks concluded that they travel an average of 115 miles a day southward with slower than the 
average flight speed of 90 miles a day at the beginning their migration. ${ }^{3}$ Hence, it is a day's flight from the Kyle area to the Dirt Hills and then another day on to the plains around Regina and from there to north of Weyburn where they overnighted during 2004 from September 20 and 27. (Records for the Regina area indicate that Swainson's Hawks all but vanish from that region by the third week of September.')

\section{Souris River drainage}

Other Saskatchewan records come from locations along this flyway over the Souris River watershed. A flock of 23 flying by Mainprize Park on the Souris River on September 27, 1986 was noted by Guy Wapple. That evening a further 105 were seen south of Mainprize Park at Henry and Della Pederson's farm. The next day heading back northwest, Guy counted 425+ Swainson's Hawks, at midday outside of Weyburn. ( GJ. Wapple, pers. comm.) Similarly, we sighted almost 2,000 on the Souris River watershed at Nickle Lake on September 28, 2001 ${ }^{2}$ and a flock was seen this year on September 26 going south by southeast over Goodwater.

\section{Des Lacs and Sheyenne rivers}

This flight path continues on into North Dakota where the largest flock for that state300 Swainson's Hawks-was seen on September 26, 1986 at the southernmost bend of the Souris River (Ron Martin, pers. comm.). Along the Des Lacs River valley, they are seen yearly at the end of September and into the beginning of October (Bob Murphy, pers. comm.).

In 2004, the first sighting on September 25 of a flock of 50 Swainson's Hawks in North Dakota was on the edge of the Sheyenne Valley in Beane County in southeast part of the state. (Ron Martin, pers. comm.) From there the Sheyenne River runs in a southeasterly direction to meet the Wild Rice River. River systems continue south into South Dakota and past where the Missouri Coteau ends at the border of Nebraska and South Dakota.
A radio collared Swainson's Hawk that went southeast from Kindersley, Saskatchewan, on August 26, 1996 appears to have funneled along the Souris River basin into North Dakota as the aforementioned birds did, then down the Missouri River basin, and then east of the Missouri Coteau into Nebraska. ${ }^{4}$

While the telemetry mentioned in this article cannot be used to fine tune recurring flight paths for Swainson's Hawks in Saskatchewan, ("Most radios were programmed to send a signal [one to four times in eight hours] every sixth day") ${ }^{5}$ our observations echo this work. ${ }^{3}$ The general direction of the prevailing surface winds between September and November in the Province (out of the northwest) correlate with the direction that the Swainson's Hawk with the radio pack flew, as did the prevailing winds in the spring with that bird's return flight to Kindersley the next year. ${ }^{4,5}$

\section{Conclusion}

Much of the hawk behaviour we observed was governed by daylight, winds, and differences in air and ground temperature. They do not move at night, nor feed before the ground warms up and sparks their food supply (grasshopper) to activity. The hawks only flew away when rising air and wind currents were in their favour.

Birders' observations and inferences based on radio telemetry point to a migration route out of Saskatchewan that follows the eastern edge of the Missouri Coteau and the Souris River basin.

There are unseen currents of air over the Northern Plains, rivers and valleys to follow, and man-made places where Swainson's Hawks find food and refuge. It will require patience and further systematic observations of Swainson's Hawk migratory flights to link together all of the Swainson's Hawk pathways through Saskatchewan and North Dakota and onward to Central America. Nevertheless, the 
direction of flight inferred from the map accompanying this article follows some of the characteristics of the movement of air on the Wind Energy Flow Map for NorthAmerica. ${ }^{12}$ The direction of a major wind energy flow coincides with that of the Swainson's Hawk's flight from west-central Saskatchewan to the southeast and then due south at the American border to eventually curl west as it enters Texas. " Hence, the probable flight path for the SWHA leaving Saskatchewan from the southeast would be to fly south staying east of the Missouri Coteau and west of the Pembina Escarpment as does this wind system through North Dakota.

Continuing east of the Missouri Coteau through South Dakota and west of the Prairie Coteau, the hawks are funneled into Nebraska where "very large flocks have been observed." 8 Flocks of 100 or more Swainson's Hawks are regularly seen in the counties in southeast Nebraska and in Pottawattemie County, Iowa bordering the shore of the Missouri River across from Douglas County, Nebraska. ${ }^{9}$ The hawks then travel on through Kansas to Oklahoma and Texas where the migratory pathway is especially narrow as is the wind energy flow that originated back on the Saskatchewan plains. $^{8}$

These winds are not the strongest occurring over continental North America. ${ }^{11}$ They are strong enough to propel wind turbines but are not strong enough to make it difficult for a hawk to land or alter its direction of flight.

The importance of thermals also can be speculated upon. Of three commonly found buteos in Saskatchewan (Swainson's, Redtailed and Rough-legged hawks) Swainson's Hawks arrive on the Saskatchewan plains the latest and leave the earliest. ${ }^{1,6}$ This suggests that of the three buteos, Swainson's Hawks make the most use of thermals, which are more likely to occur when these hawks arrive here and leave this region. In comparison, Rough-legged Hawks arrive when ground temperatures are just beginning to lose their chill and migrate out when air temperatures start to fall to winter values.

One cannot but conclude that Swainson's Hawks are a paradigm of the efficient use of different types of air currents to travel great distances with the minimum expenditure of energy.

(This article is dedicated to Wayne C. Harris, who knew and cared, and drew us into his circle.)

1. ADAM, C.I.G., et. al. 1985. A Birdfinding Guide to the Regina Area. Special Publication No. 16, Saskatchewan Natural History Society, Regina.

2. BAILEY, M. 2001. Swainson's Hawks Over the Souris Valley, Blue Jay 59:207-208

3. FULLER, M.R., W.S. SEEGAR, \& L.S. SCHUECK. 1998. Routes and travel rates of migrating Peregrine Falcons and Swainson's Hawks in the western hemisphere. Joumal of Avian Biologv 29:433-440

4. FUNG, K.I. 1999. Atlas of Saskatchewan. University of Saskatchewan, Saskatoon. p. 115

5. HOUSTON, C.S. \& K.I. FUNG. 1999 Saskatchewan's first Swainson's Hawk with satellite radio. Blue Jay 57:69-72

6. LEIGHTON, A. L., et al. 2001. (eds.) Birds of the Saskatoon Area. Nature Saskatchewan, Regina.

7. ROY, J. F. 1996. Birds of the Elbow. Special Publication No. 21, Saskatchewan Natural History Society, Regina, p. 119.

8. SCHMUTZ, J.F., et. al. 1996. Southward migration of Swainson's Hawks. Blue Jay 54(2): 70

9. SHARPE, R.S., et.al. 2001. Birds of Nebraska. University of Nebraska Press, Lincoln.

10. WAPPLE, R. A Saskatchewan gathering of Swainson's Hawks in fall, 2002. Bhıe Jay 62:49- 52

11. www.bergey.com/Maps/OK.Wind.htm (click on maps)

12. www.windatlas.ca 